\title{
PERANCANGAN INFOGRAFIS SHELTER BANGUNAN DI KAWASAN UNIVERSITAS NEGERI PADANG SEBAGAI MITIGASI BENCANA ALAM GEMPA DAN TSUNAMI
}

\author{
Dwi Mutia Sari ${ }^{1 *}$, Hendra Afriwan ${ }^{2 *}$, Eko Purnomo ${ }^{3 *}$, Maltha Kharisma ${ }^{4 *}$
}

\author{
Program Studi Desain Komunikasi Visual Jurusan Seni Rupa Fakultas Bahasa dan Seni \\ Universitas Negeri Padang \\ Jl. Prof. Dr. Hamka, Air Tawar Padang, Kel. Air Tawar Barat, Kec. Padang Utara, Kota Padang, Kode Pos 25137 \\ Sumatera Barat. Indonesia \\ Email: mutia2011@fbs.unp.ac.id,hendrafriwandkv@gmail.com,ekopurnomoar@gmail.com, \\ maltha.kharisma@fbs.unp.ac.id
}

\begin{abstract}
Abstrak
Perancangan infografis shelter bangunan di kawasan Universitas Negeri Padang (UNP) ini diangkat berdasarkan fakta bahwa di UNP belum tersedianya sebuah informasi grafis mengenai shelter bangunan yang digunakan sebagai mitigasi gempa dan tsunami di Kota Padang. Hal tersebut menjadi penting sekali untuk diketahui oleh civitas akademik maupun masyarakat yang berada di sekitaran UNP Padang sebagai salah satu mitigasi atau usaha penyelamatan apabila terjadi bencana gempa dan tsunami yang mengancam keselamatan secara tiba-tiba, sehingga civitas akademik dan masyarakat mengetahui bangunan-bangunan mana saja yang dapat dijadikan shelter penyelamatan apabila terjadi bencana tersebut. Artikel ini merupakan salah satu hasil penelitian dasar dengan menggunakan metode Research and Development (R\&D), metode ini digunakan untuk memudahkan proses kreatif dalam dalam perancangan dan proses produksi. Hasil penelitian ini adalah prototype flyer infografis peta shelter bangunan di kawasan UNP.
\end{abstract}

Kata Kunci: infografis, mitigasi bencana, UNP.

\begin{abstract}
This infographic design of building shelters in the Padang State University (UNP) area was appointed based on the fact that at UNP there is no graphic information about building shelters used as earthquake and tsunami mitigation in Padang City. This is very important to be known by the academic community and the community around UNP Padang as one of the mitigation or rescue efforts in the event of an earthquake and tsunami that threatens safety suddenly, so that the academic community and the public know which buildings are located. which can be used as a rescue shelter in the event of a disaster. This article is one of the results of basic research using the Research and Development $(R \& D)$ method, this method is used to facilitate the creative process in the design and production process. The result of this research is a prototype flyer infographic map of building shelters in the UNP area.
\end{abstract}

Keywords: infographics, disaster mitigation, UNP.

\section{PENDAHULUAN}

Pada tanggal 30 September 2009 pukul 17:16:10 WIB, terjadi gempa bumi di lepas pantai Sumatra Barat atau sekitar $50 \mathrm{~km}$ barat laut Kota Padang, dengan kekuatan 7,6 skala richter. Gempa menyebabkan kerusakan parah di beberapa wilayah di Sumatra Barat seperti Kota Padang, Kabupaten Padang Pariaman, Kabupaten Pesisir Selatan, Kota Pariaman, Kota Bukittinggi, Kota Padangpanjang, Kabupaten Agam, Kota Solok, dan Kabupaten Pasaman Barat. Menurut data Satkorlak PB, sebanyak 1.117 orang tewas akibat gempa ini yang tersebar di 3 kota dan 4 kabupaten di Sumatra Barat, korban luka berat mencapai 1.214 orang, luka ringan 1.688 orang, dan korban hilang 1 orang. Selain itu mengakibatkan sebanyak 135.448 rumah rusak berat,
65.380 rumah rusak sedang, dan 78.604 rumah rusak ringan. Upaya penanggulangan bencana dengan pengiriman bantuan dari luar wilayah Sumatera Barat cukup susah karena terputusnya komunikasi dan akses keluar masuk karena jalan yang rusak parah, sehingga mengakibatkan korban tewas terus bertambah. Pada tanggal 13 Oktober 2009, tercatat angka korban tewas di Sumatera Barat meningkat menjadi 6.234 jiwa.

Melihat tingginya risiko yang diakibatkan oleh gempa bumi patahan ini yang berdampak pada korban jiwa, maka perlu adanya upaya-upaya peningkatan mitigasi dan pengurangan risiko bencana, yakni salah satunya adalah dengan adanya pengetahuan tentang informasi mitigasi bencana tersebut (BPBD, 2021). 
Karena belum adanya infografis mengenai shelter bangunan di UNP Padang sebagai mitigasi bencana alam gempa dan tsunami tersebut, maka perlunya dibuatkannya informasi berupa infografis shelter bangunan sehingga civitas akademik maupun masyarakat memiliki panduan dan pemahaman terkait bahaya, cara mewaspadai, informasi jalan atau akses menuju ke bangunan atau lokasi aman dari gempa dan tsunami dalam bentuk media flyer. Yang mana UNP akan ikut berperan aktif dalam penyadaran kembali kepada masyarakat di sekitar lingkungan universitas, para mahasiswa, pihak universitas dalam menghadapi bahaya gempa atau tsunami dimasa yang akan datang.

\section{KAJIAN TEORI}

\section{Infografis}

Menurut Newsom (2004) Grafis informasi atau infografis adalah representasi visual yang grafis informasi, data yang atau pengetahuan dimaksudkan untuk menyajikan informasi yang kompleks. Infografis mencakup presentasi visual yang dapat menjelaskan rangkaian cerita atau proses dari serangkaian data dengan menggunakan berbagai elemen seperti gambar, ilustrasi, tipografi, peta dan visualisasi (Dur, 2014). Sehingga dapat dipahami bahwa infografis ini merupakan teknik dalam menyajikan informasi secara visual /grafis sehingga dapat dipahami oleh pembacanya.

Shafipoor (2016) menjelaskan bahwa infografis dapat dikategorikan kedalam empat kelas utama yaitu: a) Infografis statis Infografis statis adalah ifografis yang disajikan dalam bentuk visual statis, tanpa konsep audio atau konsep animasi yang bisa bergerak. b) Infografis animasi Infografis jenis ini dapat digunakan pada media audio visual seperti televisi atau youtube. Infografis animasi dapat disajikan dalam bentuk 2 dimensi maupun 3 dimensi yang tampak lebih kompleks. c) Infografis interaktif Infografis interaktif adalah jenis infografis yang paling kompleks. Infografis interaktif adalah infografis yang ditampilkan pada website dan pengguna dapat berintraksi dengan informasi yang ditampilkan melalui user interface yang telah di-desain. d) Infografis fisik Infografis fisik adalah jenis infografis yang penyajian datanya dalam bentuk tiga dimensi.

\section{Mitigasi Bencana}

Pasal 1 (2008) Tentang Penyelenggaraan Penanggulangan Bencana dijelaskan bahwa mitigasi bencana adalah serangkaian upaya untuk mengurangi risiko bencana, baik melalui pembangunan fisik maupun penyadaran dan peningkatan kemampuan menghadapi ancaman bencana.
Dalam situs BPBD (2021) menjelaskan tujuan dari mitigasi bencana yaitu: a) mengurangi dampak yang ditimbulkan, khususnya bagi penduduk, b) sebagai landasan (pedoman) untuk perencanaan pembangunan, c) meningkatkan pengetahuan masyarakat dalam menghadapi serta mengurangi dampak/resiko bencana, sehingga masyarakat dapat hidup dan bekerja dengan aman.

\section{Universitas Negeri Padang (UNP)}

UNP (2021) dijelaskan bahwa Universitas Negeri Padang (UNP) adalah hasil konversi IKIP Padang menjadi universitas, yang pada mulanya bernama Perguruan Tinggi Pendidikan Guru (PTPG). Semenjak didirikan pada tanggal 23 Oktober 1954, UNP telah mengalami banyak perubahan. Perubahan ini dapat diklasifikasikan dalam lima periode, yaitu periode PTPG Batusangkar, periode FKIP Universitas Andalas Bukittinggi di Batusangkar, periode FKIP Universitas Andalas Padang, periode IKIP Jakarta Cabang Padang, periode IKIP Padang dan periode UNP. Adapun visi, misi, tujuan dan motto UNP adalah sebagai berikut:

\section{1). Visi}

menjadi Universitas Unggul dan Bermartabat di Asia.

\section{2). Misi}

1) menyelenggarakan pendidikan dan pembelajaran yang berkualitas, 2) melaksanakan riset berbasis inovasi, 3) mentransformasikan hasil riset untuk peningkatan kualitas kehidupan dan kesejahteraan masyarakat, 4) menerapkan tata kelola universitas yang baik; dan 5) menyelenggarakan kerjasama yang produktif dan bereputasi global.

\section{3). Tujuan}

1) menghasilkan lulusan yang unggul dan berkarakter, 2) meningkatkan kuantitas dan kualitas riset berbasis inovasi, 3) menguatkan kapasitas inovasi, 4) meningkatkan kuantitas dan kualitas sumber daya manusia, 5) meningkatkan kontribusi UNP untuk kualitas kehidupan dan kesejahteraan masyarakat, 6) mewujudkan tata kelola Universitas yang transparan, akuntabel, bertanggung jawab, dan adil, 7) mewujudkan universitas yang mandiri (PTN-BH) dan 8) meningkatkan kuantitas dan kualitas kerjasama yang produktif dan bereputasi global.

\section{4). Motto}

"Alam Takambang Jadi Guru" motto ini diartikan bahwa sivitas akademika Universitas Negeri Padang selalu responsif dan proaktif terhadap lingkungannya. 


\section{METODE PENELITIAN}

Penelitian ini dirancang dengan menggunakan metode Research and Development $(R \& D)$, yang mana Sugiyono (2016) menjelaskan bahwa proses perancangan dengan menggunakan metode $R \& D$ ini memiliki langkah-langkah yang menggambarkan proses pelaksanaan pengembangan yang diuraikan secara jelas, yaitu:

\section{Potensi dan Masalah}

Infografis shelter bangunan mitigasi gempa dan tsunami merupakan salah satu wujud nyata konstribusi UNP Padang terhadap masyarakat sekitar dengan menyediakan informasi penting mengenai mitigasi penyelamatan apabila terjadi gempa dan tsunami yang dapat membantu mengurangi resiko bayaknya korban dalam bencana tersebut nantinya. Infografis ini diharapkan dapat dimiliki oleh civitas akademik dan masyarakat sekitaran Universitas Negeri Padang sehingga dapat digunakan sebagai panduan tentang gedung mana saja yang aman dan dekat dari lokasi mereka berada guna dijadikan tempat penyelamatan ketika terjadi bencana tsunami. Masalah yang dihadapi pada saat ini adalah belum adanya infografis mengenai shelter bangunan yang digunakan sebagai mitigasi gempa dan tsunami bagi civitas akademik dan masyarakat di sekitaran UNP Padang yang dapat dijadikan panduan sebagai usaha penyelamatan tersebut.

\section{Pengumpulan Data}

Data yang diperlukan penelitian ini adalah data yang $u p$ to date dan berkaitan dengan UNP Padang antara lain mengenai informasi gedung mana saja yang dapat dijadikan shelter yang sesuai dengan syarat penyelamatan apabila terjadi bahaya tsunami. Selain itu diperlukan pula informasi tentang titik kumpul serta jalur evakuasi sebagai petujuk arah bagi civitas akademik dan masyarakat apabila terjadi bencana gempa.

\section{Desain}

Metode perancangan yang digunakan adalah metode mind mapping dengan cara mengidentifikasi data secara verbal maupun visual menjadi konsep visual yang diaplikasi menggunakan ikon/symbol, warna serta grafis selanjutnya disusun menjadi sebuah rancangan yang diaplikasikan pada flyer shelter mitigasi gempa dan tsunami di kawasan UNP Padang ini. Perancangan desain ini akan dibantu oleh tenaga ahli dalam bidang grafis.

\section{Validasi Desain}

Rancangan yang sudah dbuat dan diaplikasikan ke dalam flyer nantinya akan dilakukan validasi guna mendapatkan sebuah bentuk infografis yang simple sehingga mudah dipahami. Valisasi tersebut akan dilakukan oleh tenga ahli yang ahli di bidang Desain Komunikasi Visual.

\section{Revisi Desain}

Hasil validasi dijadikan bahan acuan dalam merevisi hasil rancangan visual nantinya sebagai bentuk penyempurnaan rancangan sebelum rancangan diproduksi.

\section{Uji Coba Produk}

Produk yang sudah diproduksi akan dilakukan uji coba produk untuk mengetahui bagaimana tingkat keterbacaan (readability), kejelasan (legibility) dan uji kesederhanaan (simplicity).

\section{Revisi Produk}

Revisi produk dilakukan jika ditemukan kejanggalan terkait prinsip desain yang ada seperti tingkat keterbacaan (readability), kejelasan (legibility) dan uji kesederhanaan (simplicity), untuk kemudian diproduksi lagi dalam jumlah terbatas.

\section{Uji Coba Pemakaian}

Dimana pada tahapan ini dicoba untuk melakukan pengamatan langsung pada uji pemakaian flyer.

\section{Revisi Produk}

Hal ini dilakukan apabila dalam pemakaian di lingkup yang lebih luas terdapat kekurangan dan kelemahan. Dalam uji coba pemakaian, akan dievaluasi bagaimana kinerja produk sehingga dapat digunakan untuk penyempurnaan dan pembuatan produk baru lagi.

\section{Produksi Produk}

Kesiapan dari desain untuk diproduksi dalam bentuk flyer peta shelter mitigasi bencana gempa dan tsunami di kawasan UNP.

\section{HASIL DAN PEMBAHASAN \\ 1.Hasil}

Adapun hasil dari penelitian ini berupa flyer infografis shelter bangunan mitigasi gempa dan tsunami. Desain ini dirancang dengan menggunakan metode Research and Development (R\&D) dengan langkah-langkah sebagai berikut:

\section{1). Potensi dan Masalah}

Infografis shelter bangunan mitigasi gempa dan tsunami merupakan salah satu wujud nyata konstribusi UNP Padang terhadap masyarakat sekitar dengan 


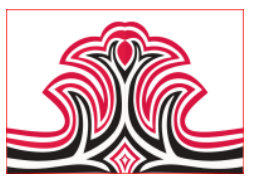

menyediakan informasi penting mengenai mitigasi penyelamatan apabila terjadi gempa dan tsunami yang dapat membantu mengurangi resiko bayaknya korban dalam bencana tersebut nantinya. Infografis ini diharapkan dapat dimiliki oleh civitas akademik dan masyarakat sekitaran Universitas Negeri Padang sehingga dapat digunakan sebagai panduan tentang gedung mana saja yang aman dan dekat dari lokasi mereka berada guna dijadikan tempat penyelamatan ketika terjadi bencana tsunami. Adapun gedung yang digunakan sebagai shelter tersebut adalah Gedung Labor Micro Teaching, Gedung Labor Ilmu Pendidikan, Gedung Pasca Sarjana, Gedung Labor Terpadu Ilmu Ekonomi, Gedung Fakultas Bahasa dan Seni, Gedung Perpustakaan dan Masjid Raya Al-Azhar (Sari, 2014). Selain itu, berdasarkan wawancara pada tanggal 7 Juni 2021 dengan Kepala Subbagian Rumah Tangga UHBMN UNP yaitu Endri (2021) juga menjelaskan adanya tambahan beberapa bangunan yang dijadikan shelter tersebut yaitu Gedung Rectorate and Researched Center UNP, Gedung UNP Hotel and Convention, Gedung Ilmu Terpadu A, Gedung Ilmu Terpadu B, SD Laboratorium Pembangunan UNP, SMP Laboratorium Pembangunan UNP, SMA Laboratorium Pembangunan UNP, Gedung Pusat PPG, 2 buah Gedung UPT-MKU UNP, dan Gedung Serbaguna FMIPA.Namun, masalah yang dihadapi pada saat ini adalah belum adanya infografis mengenai shelter bangunan yang digunakan sebagai mitigasi gempa dan tsunami bagi civitas akademik dan masyarakat di sekitaran UNP Padang yang dapat dijadikan panduan sebagai usaha penyelamatan tersebut.

\section{2). Pengumpulan Data}

Data yang diperlukan dalam penelitian ini berkaitan dengan UNP Padang antara lain mengenai informasi gedung mana saja yang dapat dijadikan shelter yang sesuai dengan syarat penyelamatan apabila terjadi bahaya tsunami. Selain itu diperlukan pula informasi tentang titik kumpul serta jalur evakuasi sebagai petujuk arah bagi civitas akademik dan masyarakat apabila terjadi bencana gempa. Informasi mengenai shelter bangunan yang ada di Kawasan UNP Penulis dapatkan dari hasil wawancara dan jurnal yang ada di UNP sendiri. Berikut ini adalah beberapa foto bangunan shelter dan titik kumpul darurat yang ada di Kawasan UNP Padang:
Gorga : Jurnal Seni Rupa

Volume 10 Nomor 02 Juli-Desember 2021 p-ISSN: 2301-5942 | e-ISSN: 2580-2380

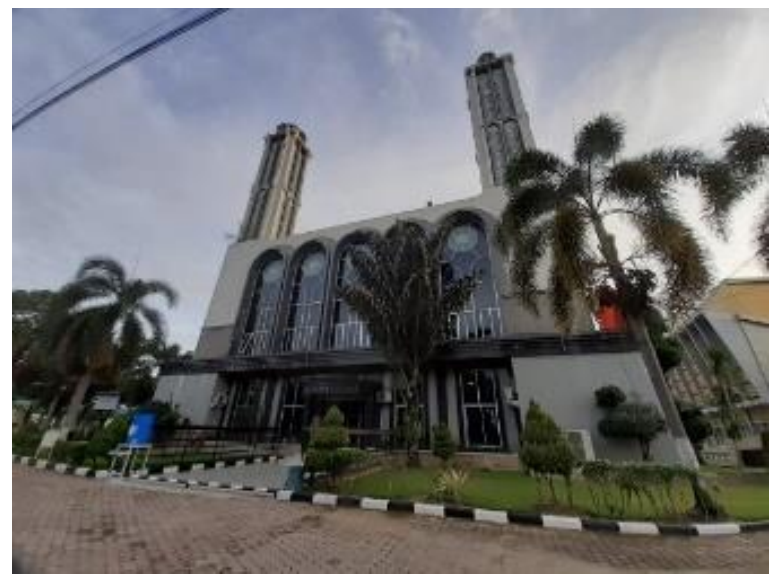

Gambar 1. Foto Masjid Raya Al Azhar (Purnomo, 2021)

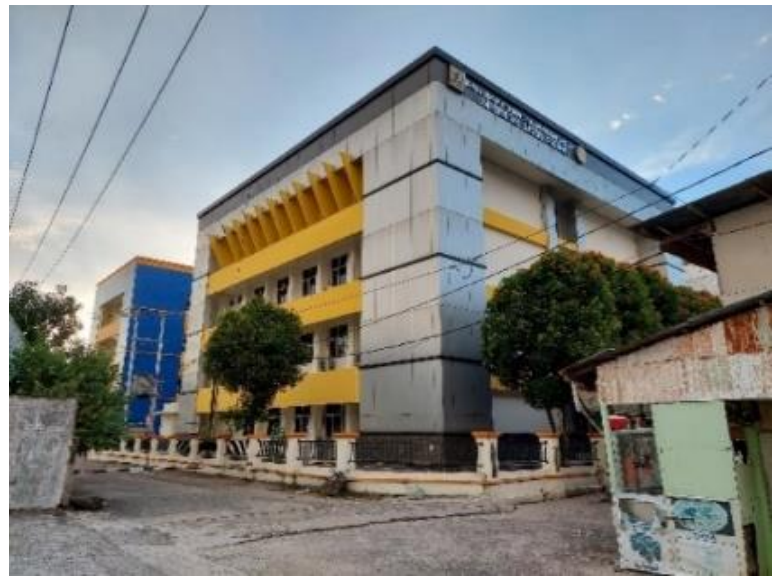

Gambar 2. Foto Gedung Pusat PPG dan UPT-MKU (Purnomo, 2021)

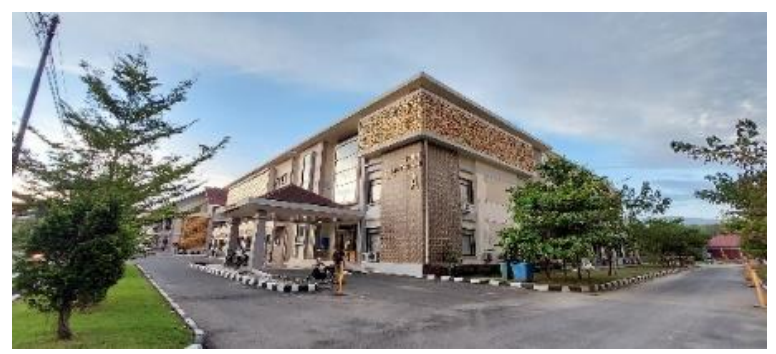

Gambar 3. Foto Gedung Kelas Terpadu A (Purnomo, 2021)

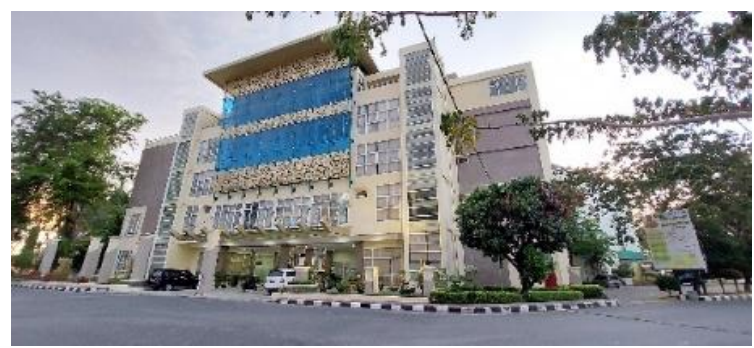

Gambar 4. Foto Gedung Fakultas Ilmu Pendidikan (Purnomo, 2021) 


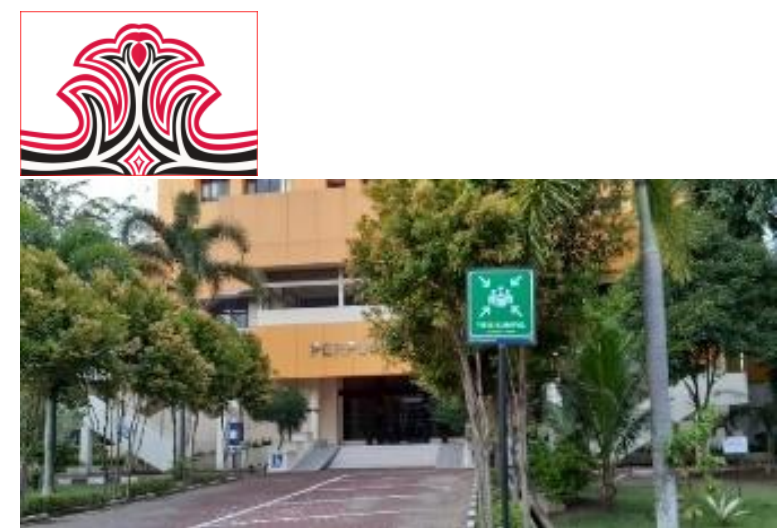

Gambar 5. Foto Titik Kumpul Darurat di Depan GEDUNG Serbaguna FMIPA

(Purnomo, 2021)

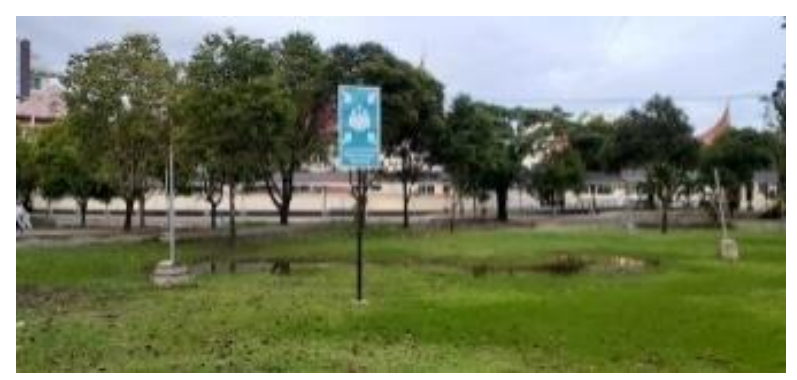

Gambar 6. Foto Titik Kumpul Darurat di Depan GEDUNG Rectorate and Researched Center UNP (Purnomo, 2021)

\section{3). Desain}

Metode perancangan yang digunakan adalah metode mind mapping dengan cara mengidentifikasi data secara verbal maupun visual menjadi konsep visual yang diaplikasi menggunakan ikon/symbol, warna serta grafis selanjutnya disusun menjadi sebuah rancangan yang diaplikasikan pada flyer shelter bangunan mitigasi gempa dan tsunami di kawasan UNP Padang ini. Perancangan desain ini akan dibantu oleh tenaga ahli dalam bidang grafis.

\section{(1). Identifikasi Data}

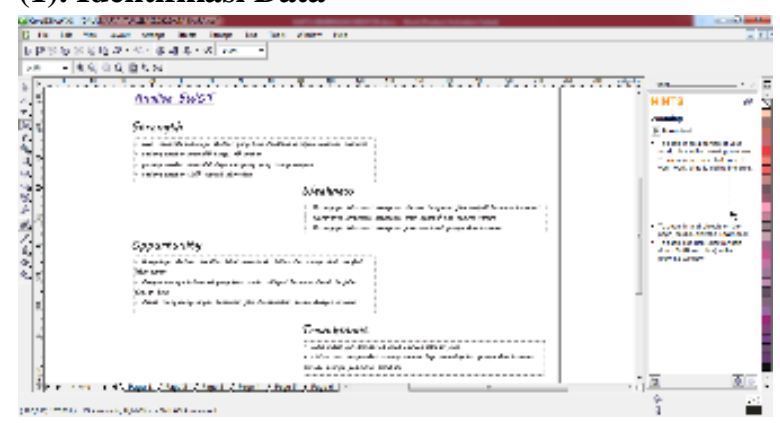

Gambar 7. Proses Analisa SWOT.

(Purnomo, 2021)
Gorga : Jurnal Seni Rupa

Volume 10 Nomor 02 Juli-Desember 2021

p-ISSN: 2301-5942 | e-ISSN: 2580-2380

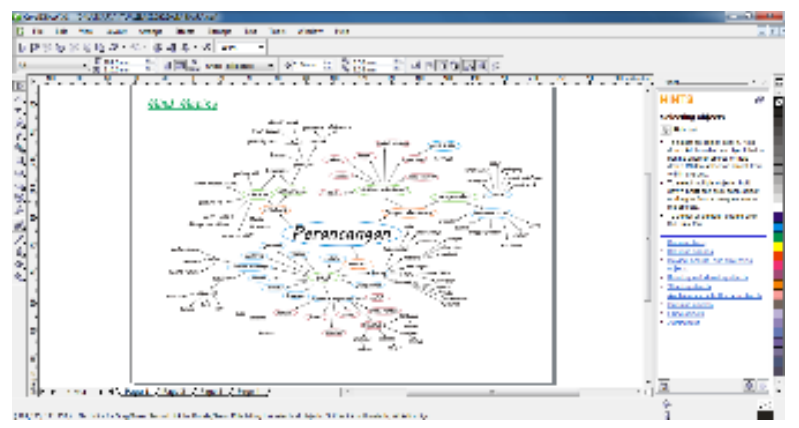

Gambar 8. Proses Pengembangan Mind Mapping (Purnomo, 2021)

\section{(2). Membuat Rancangan/Mendesain-Layout Kasar}

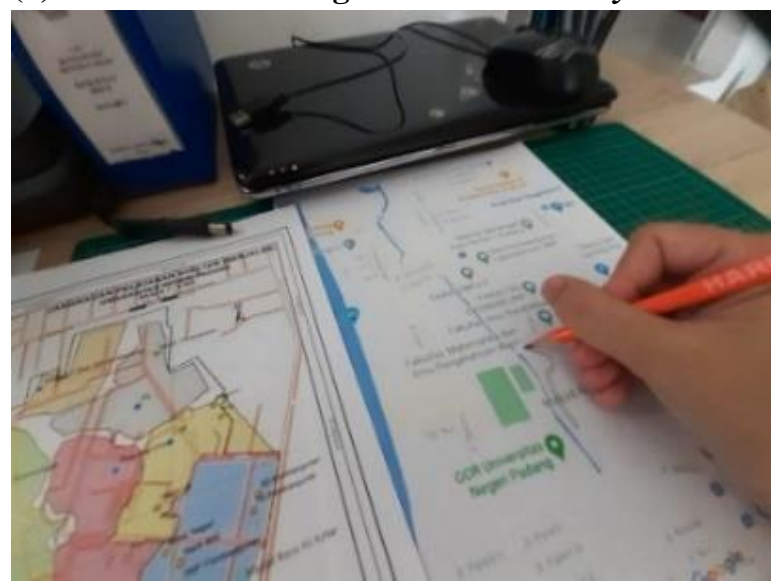

Gambar 9. Proses Tracing Map (Purnomo, 2021)

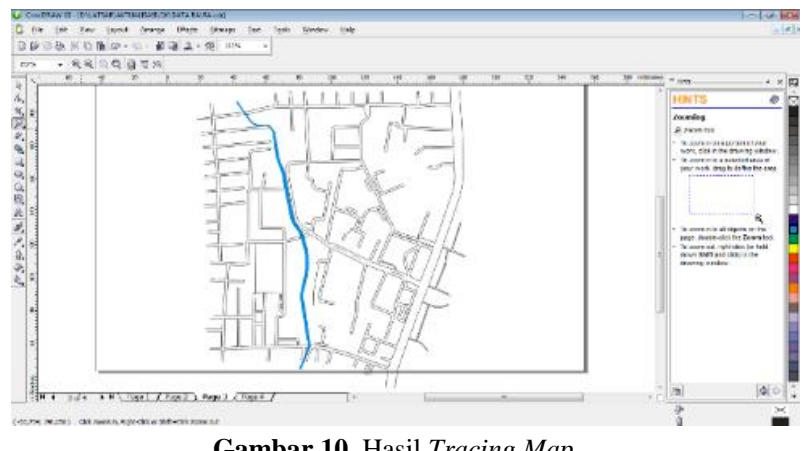

Gambar 10. Hasil Tracing Map

(Purnomo, 2021)

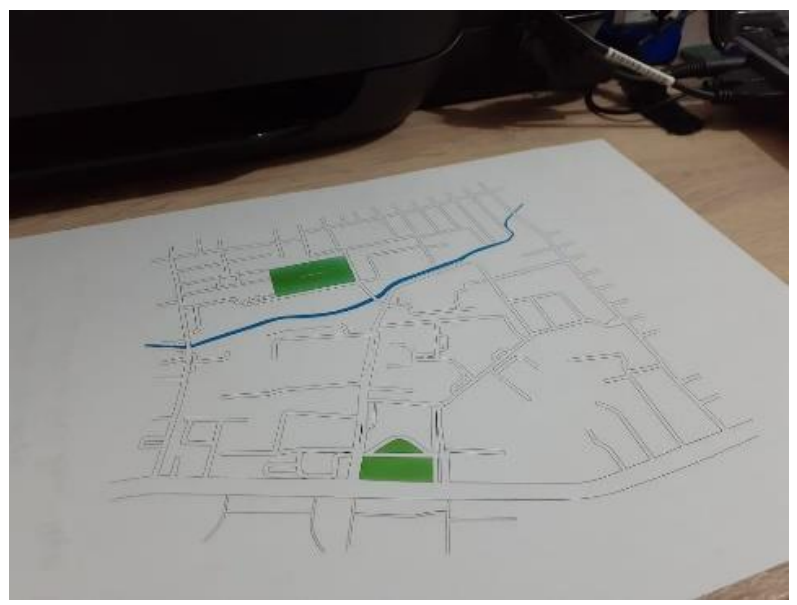

Gambar 11. Print Out Tracing Map

(Purnomo, 2021) 


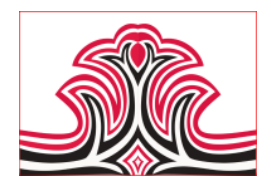

\section{(3). Membuat}

Rancangan/ Mendesain Layout

\section{Komprehensif}

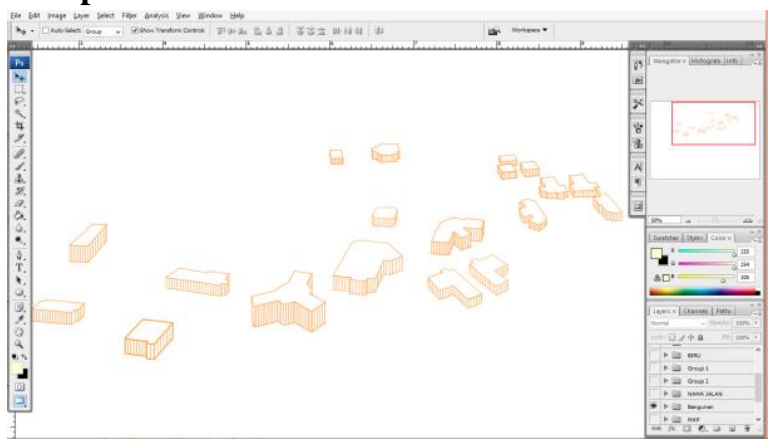

Gambar 12. Proses Pewarnaan Bangunan Secara Digital pada Map (Purnomo, 2021)

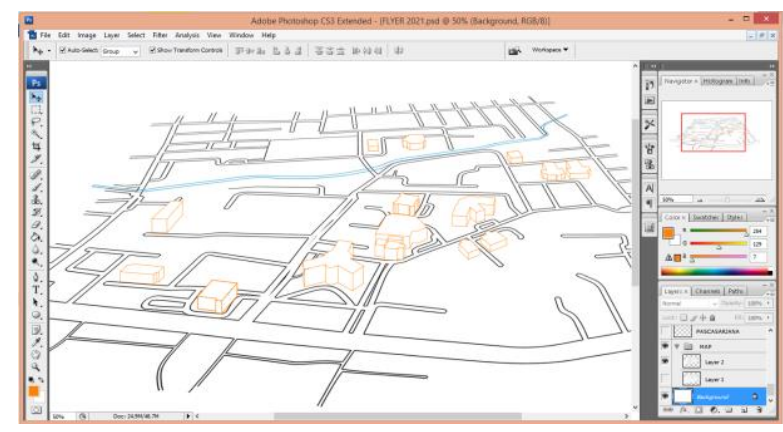

Gambar 13. Proses Pewarnaan Secara Digital pada Map (Purnomo, 2021)

\section{(4). Membuat Rancangan/ Mendesain Layout}

\section{Eksekusi}

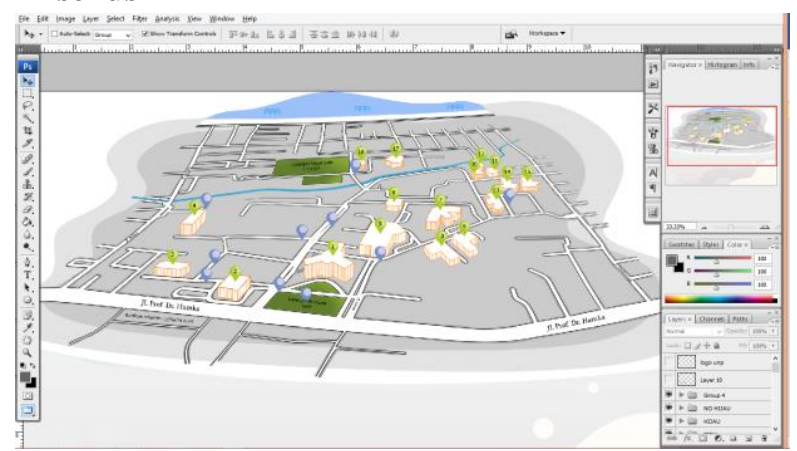

Gambar 14. Tahap Mendesain map Shelter Secara Menyeluruh (Purnomo, 2021)

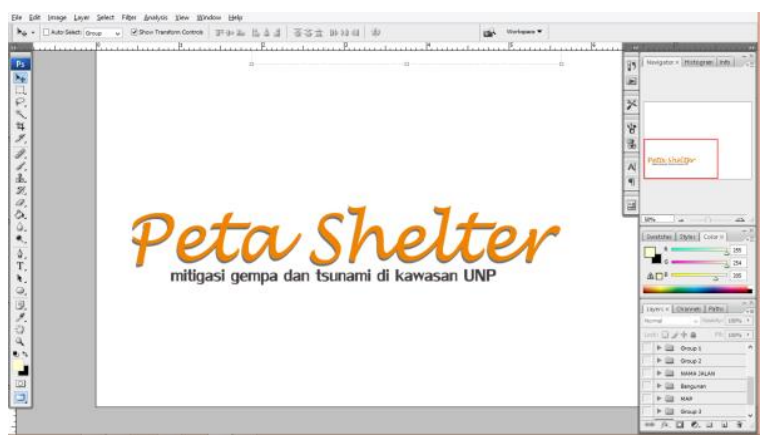

Gambar 15. Desain Judul Infografis pada Flyer

(Purnomo, 2021)
Gorga : Jurnal Seni Rupa

Volume 10 Nomor 02 Juli-Desember 2021 p-ISSN: 2301-5942 | e-ISSN: 2580-2380

\section{(5). Final Desain}

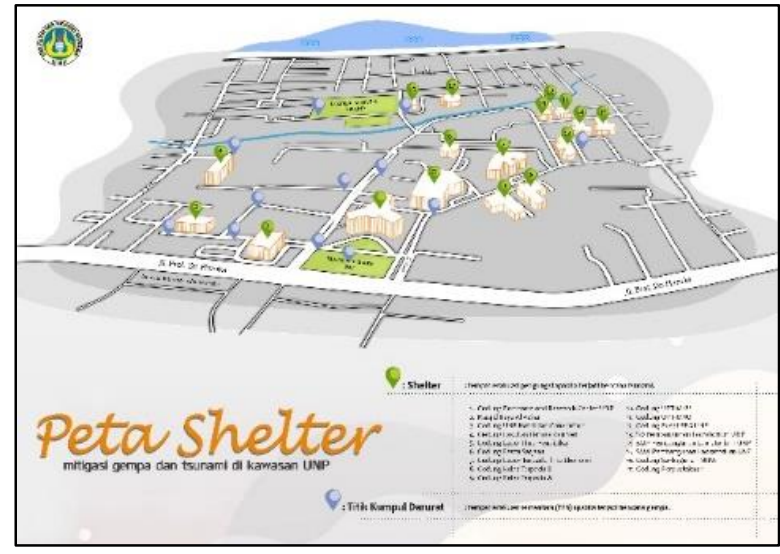

Gambar 16. Final Desain Flyer

(Purnomo, 2021)

\section{4). Validasi Desain}

Validasi desain dilakukan dengan cara menghadirkan validator/tenaga ahli yang sudah berpengalaman di bidang Desain Komunikasi Visual untuk menilai produk baru yang dirancang tersebut guna mendapatkan sebuah bentuk infografis yang simple pada rancangan yang sudah dibuat sehingga mudah dipahami. Validator/tenaga ahli diminta untuk menilai desain tersebut, sehingga selanjutnya dapat diketahui kelemahan dan kekuatannya. Hasil validasi dari validator masuk ke dalam kategori valid.

\section{5). Revisi Desain}

Hasil validasi desain yang sudah dilakukan sebelumnya maka ditemukan kekurangan dan kelemahan yang selanjutnya dijadikan acuan bagi desainer dalam merevisi hasil rancangan visual nantinya sebagai bentuk penyempurnaan rancangan sebelum rancangan diproduksi.

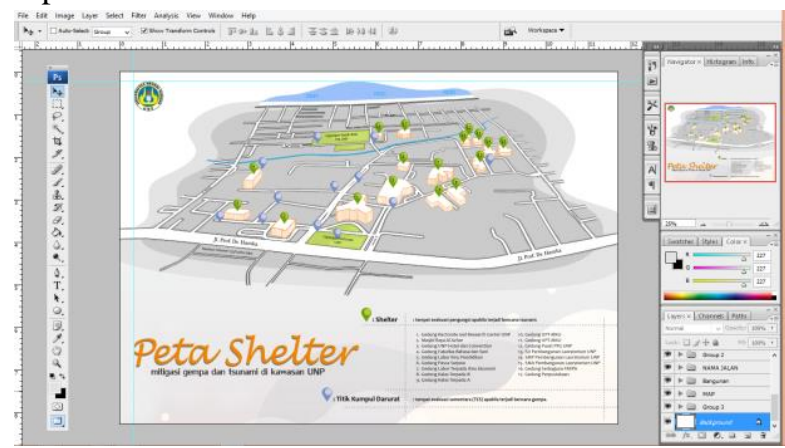

Gambar 17. Screen Capture Revisi Desain Menggunakan Software Adobe Photoshop

(Purnomo, 2021)

\section{6). Uji Coba Produk}

Produk yang sudah diproduksi akan dilakukan uji coba produk untuk mengetahui bagaimana tingkat keterbacaan (readability), kejelasan (legibility) dan uji kesederhanaan (simplicity). 


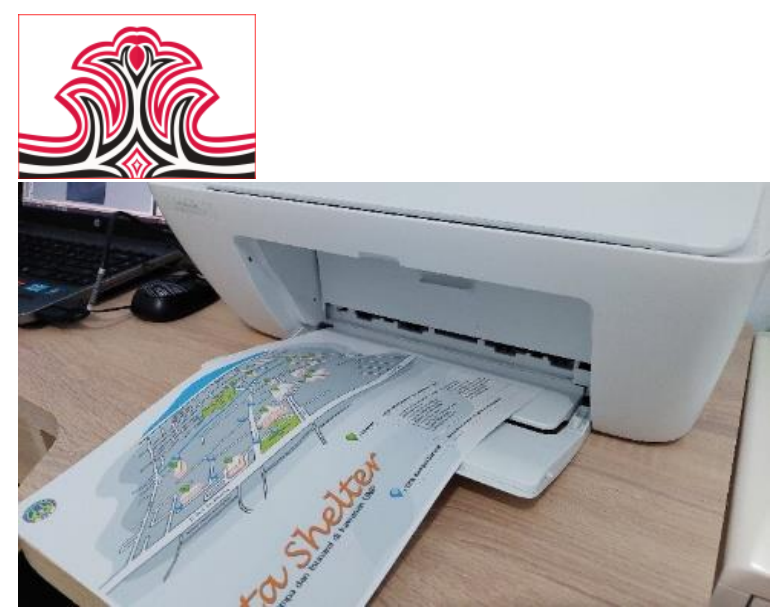

Gambar 18. Uji Coba Produk dalam Bentuk Flyer (Purnomo, 2021)

\section{7). Revisi Produk}

Revisi produk dilakukan jika ditemukan kejanggalan terkait prinsip desain yang ada seperti tingkat keterbacaan (readability), kejelasan (legibility) dan uji kesederhanaan (simplicity), untuk kemudian diproduksi lagi dalam jumlah terbatas. Namun, pada desain final flyer ini sudah dapat langsung diproduksi karena desain sudah sesuai dengan prinsip desain yang dikemukakan.

\section{8). Uji Coba Pemakaian}

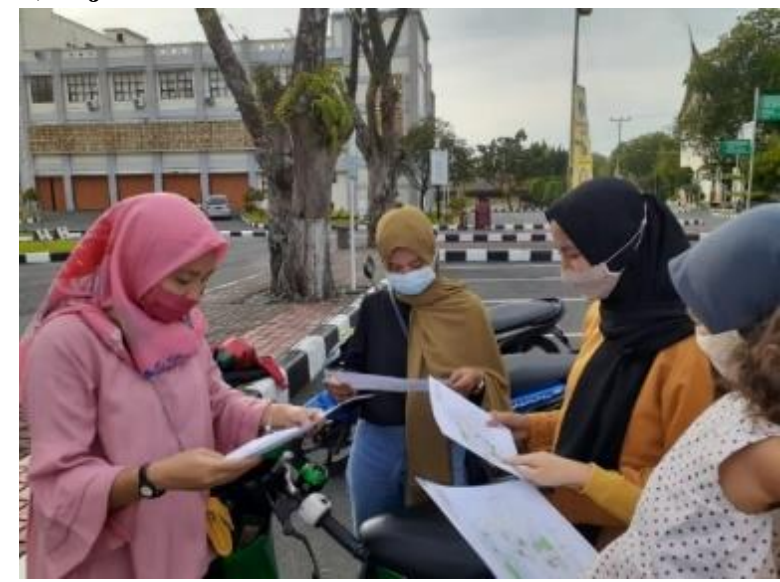

Gambar 19. Uji Coba Pemakaian Kepada Mahasiswa (Purnomo, 2021)

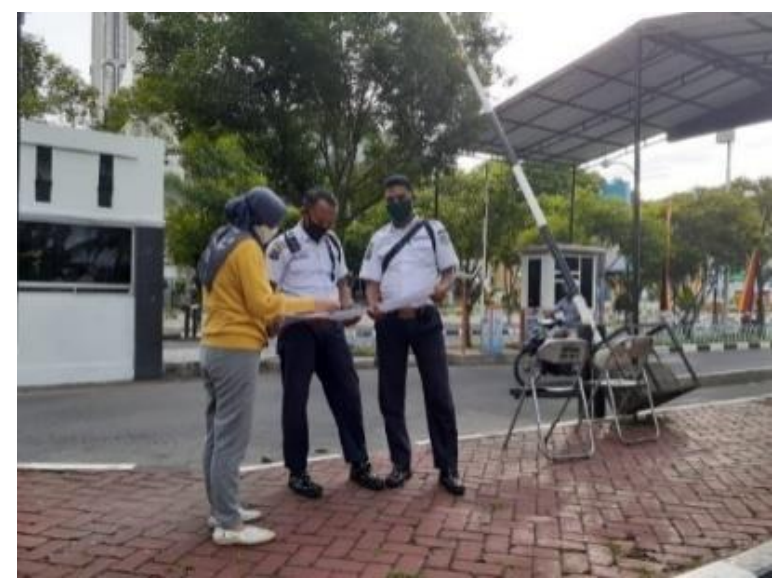

Gambar 20. Uji Coba Pemakaian Kepada Petugas Keamanan UNP (Purnomo, 2021)
Gorga : Jurnal Seni Rupa

Volume 10 Nomor 02 Juli-Desember 2021 p-ISSN: 2301-5942 | e-ISSN: 2580-2380

\section{9). Uji Coba Pemakaian}

Dalam uji coba pemakaian tidak terdapat kekeliruan dalam membaca flyer peta shelter yang sudah dirancang sehingga dapat dilanjutkan untuk memproduksi produk.

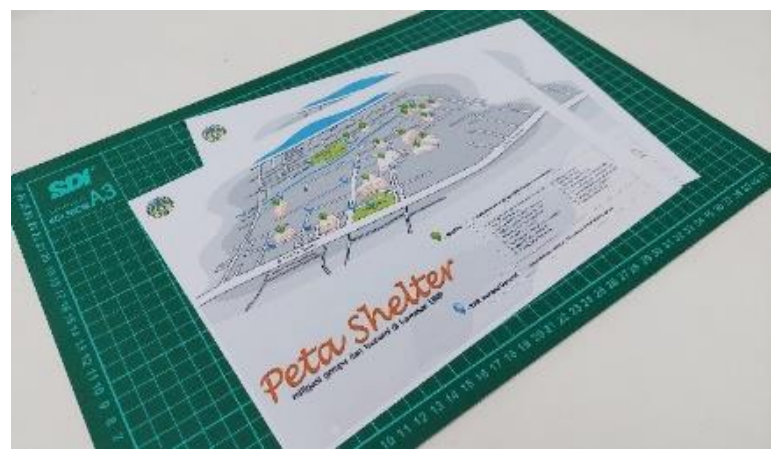

Gambar 21. Produk Flyer Peta Shelter Siap Diproduksi

(Purnomo, 2021)

\section{0). Uji Coba Pemakaian}

Kesiapan dari desain untuk diproduksi dalam bentuk flyer peta shelter mitigasi bencana gempa dan tsunami di kawasan UNP pada kertas brosur glossy art paper ukuran A4 150gsm.

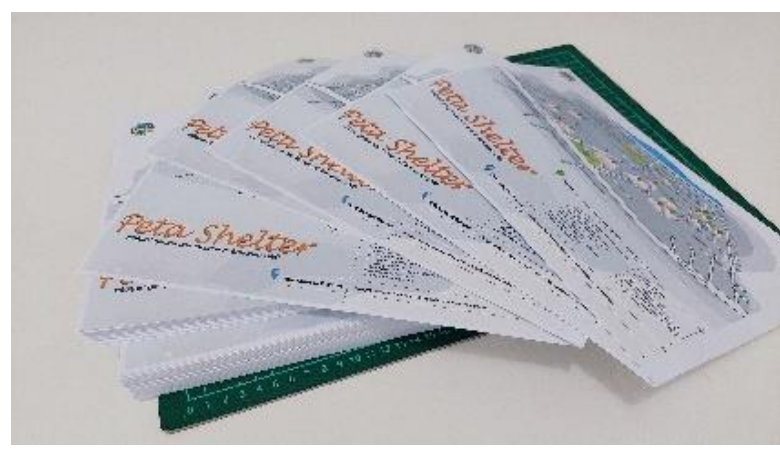

Gambar 22. Produksi Produk Flyer Peta Shelter (Purnomo, 2021)

\section{Pembahasan}

Berdasakan data yang sudah penulis dapatkan dari berbagai sumber mengenai informasi shelter bangunan di manasaja yang dapat dijadikan shelter mitigasi tsunami yang ada di kawasan UNP Padang yaitu Gedung Rectorate and Researched Center UNP, Gedung UNP Hotel and Convention, Gedung Ilmu Terpadu A, Gedung Ilmu Terpadu B, SD Laboratorium Pembangunan UNP, SMP Laboratorium Pembangunan UNP, SMA Laboratorium Pembangunan UNP, Gedung Pusat PPG, 2 buah Gedung UPT-MKU UNP, Gedung Serbaguna FMIPA, Gedung Labor Micro Teaching, Gedung Labor Ilmu Pendidikan, Gedung Pasca Sarjana, Gedung Labor Terpadu Ilmu Ekonomi, Gedung Fakultas Bahasa dan Seni, Gedung Perpustakaan dan Masjid Raya Al-Azhar. Sehingga 


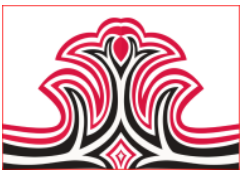

dapat dilakukan perancangan menggunakan metode Research and Development (R\&D).

\section{KESIMPULAN DAN SARAN}

1. Kesimpulan

Infografis merupakan visualisasi data, gagasan, informasi atau pengetahuan melalui bagan, grafis, jadwal dan lainnya agar data, gagasan, informasi atau pengetahuan dapat disajikan lebih dari sekedar teks dan memiliki dampak visual yang cukup kuat sehingga dapat menggugah kesadaran pembacanya untuk memahami data, gagasan, informasi atau pengetahuan lebih cepat dan tepat. Untuk itu, penting sekali merancang sebuah infografis shelter bangunan yang digunakan sebagai mitigasi gempa dan tsunami dikarenakan tingginya risiko yang diakibatkan oleh gempa bumi terjadi di lepas pantai Sumatra Barat yang sekaligus sejalan dengan tujuan pencapaian visi, misi dan Renstra Universitas Negeri Padang penelitian ini sebagai salah satu cara untuk mendukung keberhasilan UNP dalam arah kebijakan UNP tersebut.

\section{Saran}

Adanya penelitian ini kami berharap dapat memenuhi fungsinya sebagai khasanah ilmu pengetahuan. Sesuai dengan hasil pembahasan yang sudah dijelaskan diatas kami berharap infografis shelter bangunan Kawasan UNP ini dapat dijadikan salah satu mitigasi penyelamatan sehingga civitas akademik maupun masyarakat memiliki panduan dan pemahaman terkait bahaya, cara mewaspadai, informasi jalan atau akses menuju ke bangunan atau lokasi aman dari gempa dan tsunami dalam bentuk media flyer tersebut.

\section{DAFTAR RUJUKAN}

BPBD. (2021). Hari Kedua Pencarian Laka Air. bpbd.sumbarprov.go.id (diakses tanggal 22 Februari 2021).

Dur, B. I. U. (2014). Data Visualization and Infographics in Visual Communication Design Education at The Age of Information. Journal of Arts and Humanities, 3(5), 39-50.

Endri. (2021). "Tambahan Bangunan yang Dijadikan Shelter". Hasil Wawancara Pribadi: 17 Juni 2021, Universitas Negeri Padang.

Shafipoor, M., Sarayloo, R., \& Shafipoor, A. (2016). Infographic (Information Graphic); A Tool For Increasing The Efficiency of Teaching and Learning Processes. International Academic Journal of Innovative Research, 3(4), 39-45.

Newsom, Doug and Haynes, Jim. (2004). Public Relations Writing: Form and Style. Canada: Nelson Education.
Gorga : Jurnal Seni Rupa

Volume 10 Nomor 02 Juli-Desember 2021 p-ISSN: 2301-5942 | e-ISSN: 2580-2380

Pasal 1. (2008). Pasal 1 Ayat 6 PP No 21 Tahun 2008 Tentang Penyelenggaraan Penanggulangan Bencana. Jakarta: Buku Peraturan Penanggulangan Bencana.

Purnomo, Eko. (2021). "Hasil Dokumentasi dan Foto Gedung-Gedung di UNP”. Hasil Dokumentasi Pribadi: 02 Juni 2021, Universitas Negeri Padang.

Sari, Manda, Pebrina. (2014). Daya Tampung Shelter Evakuasi Tsunami di Universitas Negeri Padang, Air Tawar Barat. Padang: Jurusan Geografi.

Sugiyono. (2016). Metode Penelitian Kuantitatif, Kualitatif, dan $R \& D$. Bandung: Penerbit Alfabeta.

UNP (2021). Hasil Konversi IKIP Padang Menjadi Universitas. unp.ac.id (diakses tanggal 02 September 2021). 